\title{
Conduit versus content: a model of the firm's market involvement and organisational competitiveness
}

\author{
Eliezer Geisler* \\ Stuart School of Business, \\ Illinois Institute of Technology, \\ 565 W. Adams Street, \\ Chicago, IL 60661, USA \\ Email: geisler@stuart.iit.edu \\ *Corresponding author

\section{Giuseppe Turchetti} \\ Scuola Superiore Sant'Anna, \\ Piazza Martiri della Liberta, 33, \\ 56127 Pisa, Italy \\ Email: g.turchetti@sssup.it
}

\begin{abstract}
This paper proposes a new model of the fundamental makeup of the firm. The model is a typology of the firm as conduit versus content. Firms are classified in this model by their function in the marketplace and the contributions they bring to their environment. The firm as conduit has a function of intervening in a market transaction as a go-between or facilitator. The firm as content has a function as a provider of its outputs to the market. The CVC model also describes the strategic competitiveness of the firm as $\mathrm{CVC}$, and the differences between how the firm as conduit conjures its attributes into a competitive architecture, versus how the firm as content behaves. The unique contributions of the CVC model to the strategy and organisational analyses are described. Examples of the explanatory power of the CVC model are given in the case of the Uber transportation company, and in the case of the failed merger between AOL and Time-Warner. Further research is suggested to empirically test the CVC model, and the paper concludes with the potential applications of the model in a variety of sectors and industries, including the area of technology management.
\end{abstract}

Keywords: conduit; content; conduit versus content; CVC; competitiveness; market involvement; genetics; DNA; strategy; core competencies; structure.

Reference to this paper should be made as follows: Geisler, E. and Turchetti, G. (2018) 'Conduit versus content: a model of the firm's market involvement and organisational competitiveness', Int. J. Technology Management, Vol. 76, Nos. 1/2, pp.137-162.

Biographical notes: Eliezer Geisler is a Distinguished Professor at the Stuart School of Business, Illinois Institute of Technology, Chicago, USA. He received his Doctorate from the Kellogg School of Management at Northwestern University. He is the author and co-author of 14 books and over 100 scientific publications. His areas of research are the management of R\&D, technology, and innovation; the metrics of technology, and the foundations of knowledge management. In 2013, he was the recipient of the Medal of 
Excellence given by the Portland International Conference on the Management of Engineering and Technology (PICMET). His book: The Metrics of Science and Technology was translated into Chinese. He was the co-founder of the International Journal of Healthcare Technology Management, published by Inderscience.

Giuseppe Turchetti received his Laurea Degree in Economics from the University of Pisa and $\mathrm{PhD}$ in Management from the Scuola Superiore Sant'Anna in Pisa, where he is currently a Full Professor of Economics and Management. He spent several years as a Fullbright Research Scholar at the Kellogg School, Northwestern University at the Wharton Business School and at the Illinois Institute of Technology. His main research interests are: economics and management of innovation, economic evaluation of healthcare technologies (drugs, medical devices, e-health); structure, organisation and financing of the healthcare and long term care systems. He is author/editor of 14 books and 200 scholarly papers and book chapters.

\section{Introduction}

The nature of competition of firms in the marketplace has been widely studied from both the economic and organisational perspectives (Shieh, 2011; Prahalad and Hamel, 1990; Adegebesan, 2009). Much of this research has focused on creating models which describe the firm's effort to strategically compete (Porter, 1980; Barney and Zajac, 1994). Organisation scientists have focused on structural and behavioural variables by managers and the corporation aimed at facilitating the cooperation between organisational units, such as marketing and R\&D, and at the generation of activities and assets which would allow the firm to be strategically competitive (Brown and Blackmon, 2005; Snow and Hrebiniak, 1980).

These two streams of the literature have, by and large, developed independent trajectories. The factors that these research studies have identified contained a variety of models and conceptual as well as empirically-derived guidelines for strategic management. Most research questions were: what should the firm do to improve its competitiveness in the marketplace, and how managers should employ their resources to engender a winning strategy (Wernerfelt, 1984)?

But, these streams of research considered the firm as a generic entity. The key differentiation is the behaviour and actions of managers to strategically position their organisation (Porter, 1985; Akan et al., 2006). This generic view of the firm as a competitor in the marketplace also extends to other constructs of the nature of the market and competition, such as transaction costs (Williamson, 1979; Oliva et al., 1988).

This paper proposes a different model of the strategically competitive organisation. The basic notion of the model is the nature of the function that the firm has in the marketplace. The type of function impinges upon the genetic attributes of the firm, which in turn dictates its structure and its mode of competition. The model is: conduit versus content (CVC).

This paper is organised in four parts. The first part reviews the 'prior art' and the various models and conceptual frameworks of strategic competitiveness. The second describes the proposed CVC model, its attributes, and the ways in which it differs from extant models. The third part is an analysis of the case of the failed merger between AOL 
and Time-Warner (2000-2006). The case is analysed and reinterpreted by using the proposed CVC model. Finally, the fourth part lists and describes some applications of the CVC model in selected sectors and industries, and suggests further research to study these applications.

\section{Background}

The literature on strategic management and competitiveness has two distinct yet complementary streams. The first stream focuses on the choice of strategies and tactics by firms competing in the marketplace. The key research questions are:

1 how should the firm position itself

2 how it should use an effective strategy to better compete.

Two models have emerged in this stream. The Boston Consulting Group (BCG) has developed a growth-share matrix, which identifies different lines of business by their growth pattern and their market share, as a measure of their dominance in the market. Each line of business requires a different strategy (Hax and Mahluf, 1983; Morrison and Wensley, 1991).

Expanding on this model, BCG researchers have proposed four types of strategies, applicable across firms, their industries and their stage in their life-cycle (Reeves et al., 2015). The strategic approaches are adaptive-evolutionary, visionary or blue-ocean, shaping, and renewal. The basic idea is to provide corporate management with a palette of alternative strategies which can be used interchangeably or even simultaneously (Thacker and Handscombe, 2003).

Another model is Porter's (1980) generic strategies. This model proposes a typology of three generic competitive strategies, differentiation, overall cost leadership, and focus. The first two are considered to be mutually exclusive, whereas the focus strategy refers to a "narrow strategic target market" [Porter, (1980), p.38]. The empirical testing of this model has been non-convincing. For example, Miller and Friesen (1986a, p.51), have concluded that none of the clusters of firms they tested with Porter's generic strategies “...reflected Porter's (1980) pure types". In a supplementary paper, Miller and Friesen (1986b, p.260), concluded that "success seems to be caused by the possession of strategic advantages - the more the better - rather than strict adherence to Porter's types". Although some research has shown that Porter's strategies seem to match clusters of firms competing within their industries (Hambrick, 1983; Magretta, 2011), the link between the use of specific types of strategies and firms' performance is a more complex phenomenon. This suggests that the ability of the firm to effectively compete is influenced by the systemic nature of the firm's capabilities and by its internal structure and organisation (Murray, 1988).

Porter had acknowledged the link between structure and the generic strategies but did not adequately explain the relationship (Murray, 1988). Similarly, some research suggested that the generic strategies are not mutually exclusive, and that firms which adopted cost leadership and differentiation are shown to be very competitive and successful in their industries (Lim, 1994). The second research stream focuses on the organisational structure and the utilisation of resources by the firm to effectively implement its strategy. The key research questions in this literature are: 
1 how should the firm organise to be strategically competitive, and

2 how to best acquire and utilise its resources (Geisler, 1999b; Keidel, 1994).

\subsection{The resource-based view and core competencies}

Two models have emerged in this stream. The first is the resource-based view (RBV) of the firm, and the other is the organisational exploitation of the core competencies of the firm. Both models are based on the firm's organisational mastery of its capabilities (Geisler, 2010; Schilke, 2014). The origins of both models can be traced to Woodward (1965), Yuchtman and Seashore (1967), and Thompson (1967). Woodward (1965) reported findings from a survey of British industrial firms. She argued that different technological complexities of the production systems of these firms were associated with some organisational characteristics, so that the matching of technology and structure was positively associated with the firms' performance.

Thompson (1967) also studied the relationship between types of technologies in organisations and the structure and performance of these organisations. Thompson categorised technologies into three distinct groups and also proposed the notion of the organisation's 'core technologies'. These are the core activities of the firm, where the crucial generation of the firm's business is conducted. Thompson then suggested that the firms must organise with layers of protective boundary-spanning-roles, in order to secure the safe working of these 'core technologies'.

Yuchtman and Seashore (1967) utilised the systems approach to organisational analysis. They argued that the effectiveness of the firm and its strategic success in the marketplace are contingent upon the successful competition for resources and the effective acquisition of the resources that the firm must have to strategically compete in the marketplace.

The models proposed by Woodward (1965) and Thompson (1967) were extended by Prahalad and Hamel (1990). They advanced the notion of 'core competencies' of the firm as the basis for the firm's strategy. They argued that, "a company's competitiveness derives from its core competencies and core products (the tangible results of core competencies... Organizing around core competencies requires a radical change in corporate organization" (p.79). In order to best exploit its core competencies, the firm must structure itself in a manner which will allow the organisation to coordinate, integrate, and develop its skills, technological core and capacities, and the knowledge assets of its employees (Geisler, 1999a; Campbell et al., 2012; Yung-Hsiang and Chian-Yu, 2007).

The core competencies of the firm are mainly described in this literature as resources which are crucial to the firm's competitive strategy. There is a fine line in the different definitions of what constitutes competencies and, for example, the firm's dynamic capabilities (Holahan et al., 2014). The key difference seems to be the recruitment and alignment of the firm's internal resources to meet the external changes in its environment by implementing a proactive strategy. This is the firm's dynamic capability (Brown and Blackmon, 2005; Geisler, 2006; Oliver and Holzinger, 2008; Winter, 2003).

Aragon-Correa and Sharma (2003, p.73), defined dynamic capabilities as: “...a set of specific and identifiable processes that, although idiosyncratic to firms in their details and path dependent in their emergence, have significant compatibilities in the form of best practices across firms allowing them to generate new, value-creating strategies". They 
proposed a contingency model which links the endogenous variables of the firm (its competencies) with the exogenous variables of the dynamic business environment. This model extends the core competencies and the RBV models of the firm.

In so doing, this model focuses on the processes of proactive dynamism, but gives little consideration to the types of competencies. Other researchers extended this literature and examined specific competencies such as knowledge (Geisler, 1999a; Grant, 1996; Reed et al., 2006). Other competencies included, for example, new product development (Holahan et al., 2014), technological capabilities (Granstrand et al., 1997), and information technologies (Ray et al., 2013).

Some studies focused on specific uses of competencies in selected areas. Berman et al. (2002) examined the role that tacit knowledge plays in the competitiveness of the National Basketball Association. Similarly, Autio et al. (2000) have reported a positive relationship between knowledge intensity of entrepreneurial firms and the rate of their international growth.

The congruence of the core competencies and RBV models was articulated by Conner and Prahaled (1996). They argued that, "a theory of the firm indicates a subset of the substantive areas of endeavor likely to be associated with a company's advantage vis-à-vis other firms" (p.492). They also concluded:
"An implication of this study is that important resources, i.e., factors contributing to above-normal earnings, may include those materially affective (1) the quality of managerial as opposed to employee judgment (including, for example, organizational culture and human resources policies), and (2) the cost of implementing flexibility as to what employees should do." (p.492)

This study is a good illustration of the integration of the core competencies model and the RBV of the firm.

The RBV of the firm (Wernerfelt, 1984) is an extension of the Yuchtman and Seashore's (1967) model. The RBV model proposes the analysis of the firm's strategic options from the perspective of the procurement acquisition and utilisation of the resources it requires to function and to compete. The basis of this model is the notion that firms making adequate investments in resources and organise to utilise those resources are better equipped to maintain sustainable competitive positions in their markets (Barney et al., 2011).

The link between the RBV model and the firm's strategic competitiveness is predicated on the firm's ability to acquire and maintain resources (human, financial, technological) which are difficult to imitate but which allow the firm to combine, coordinate and exploit these resources in ways which competitors may find hard to duplicate. However, this model considers such resources to be generalised commodities. The focus of the model is not on the types of resources, their specific functions and uses, or their weaknesses and inadequacies (West and DeCastro, 2001). Another critique of the model is the fact that the RBV model does not include the underlying conditions and activities of the firm before it acquires its resources. Schmidt and Keil (2013) have identified four such exogenous variables of the firm:

1 its market position

2 its existing resource base to which additional resources can be added

3 its network of other firms

4 the knowledge and experience of its managers. 


\subsection{The current literature}

What makes the firm competitive in its marketplace? The literature has mainly focused on endogenous (e.g., knowledge) and exogenous (environmental phenomena) factors (Schmidt and Keil, 2013). Thus, the firm's ability to effectively compete was derived from its capacity to manage the endogenous variables and to match them to the changing constellation of the exogenous factors (Hambrick, 1983; Barney and Peteraf, 2014).

This literature can be distilled to the notions originally proposed by Thompson (1967) and Yuchtman and Seashore (1967). The theoretical progress made in the past 40 plus years has been limited to proposed tactical configurations of the positioning of endogenous variables in the service of a strategic aim. The questions regarding the attributes of firms which may explain the differences in the sustained competitiveness of these firms remain unanswered.

The strategy and the organisational literatures have also focused on the different configurations of the internal variables that are amenable to managerial manipulation. When managers develop a strategic vision and a corresponding plan, they employ these configurations in an architecture which takes into account the environmental realities in which their firms operate (Tosi, 2008; Viladsen, 2013). The nature of the firm, as a manifestation of its function in the market, has received limited attention, primarily in the segment of the literature on the evolutionary aspects of organisations (Hannan and Freeman, 1993).

This segment of the literature espouses the theory of the Darwinian process of organisational competition and survival, and has advanced the notion that firms behave as members of populations, hence biological phenomena of population ecology, such as natural selection will apply to them as well (Carroll and Hannan, 1995). The appeal of Darwin's theory of evolution has extended to several disciplines, including the social and the organisational sciences. An example is the application of natural selection processes to human knowledge, is known as evolutionary epistemology (Heyes and Hull, 2001).

The theory of natural selection and the survival of firms which best adapt themselves to changes in their environment has also advanced the notion that the inherent characteristics or traits of the organisation may impinge upon its ability to compete, to adapt, and to survive. These inherent factors may not be a substitute for effective strategies, but they are a contributing set of factors which may better explain the different outcomes of successful survival or the strategic failure of the firm (Usher and Evans, 1996).

The application of the theory of natural selection to the population of firms competing in their markets - an attractive a theory as it was - had created an apparent conflict with the strategy literature (Usher and Evans, 1996). The question arose: to what extent is the survival or failure of firms the result of their inherent ability to adapt to ecological changes, versus the effect of institutional changes driven by strategic management? Singh and Lumsden (1990) have suggested that there is a growing convergence of these two theoretical approaches. However, they also examined criticism of the organisational ecology school of research. The key argument has been and is still current and valid: "the most commonly shared belief is that ecological thinking is determinism, as opposed to volunturistic, and that marginal agency and free will are denied in this approach" (p.184).

Although some convergence of these divergent research streams has emerged, the apparent conflict between ecological and institutional-strategic approaches illustrates the key gaps in the literature. All firms are considered alike, with minor distinctions. The 
differentiated attributes are dictated by the industry or sector to which the firms belong. The models examined in this review of the literature have offered an ecological explanation of how the firm behaves and competes, based upon the effects of the random fit of the firm with changes in its relevant environment. This paper also describes the nature of such ecological characteristics.

The purpose of this paper is two-fold. First, it provides a novel model of the firm as it competes in a dynamic environment. Second, this paper contributes to the literature by suggesting that inherent differentiating characteristics of the firm can be constructed.

\section{CVC: description of the model}

The CVC model is based on the notion that firms can be differentiated and meaningfully analysed by means of their function in their marketplace. This is a template for the identification of the nature of the firms. This nature of the firm is assumed to be consistent across sectors and industries.

The strategic questions embedded in the foundation of the CVC model are:

1 What is our business? This is not simply the firm's relation to an industry (a set of similar firms), but a more fundamental question of what it is that we do in our market?

2 What is our function in the market? This is not simply the description of the firm's products or services, but rather the function refers to the role that the firm plays in the complex environment in which it operates.

The CVC model extends beyond the existing models, in which the characteristics of the firm are dictated by its membership in an industry. The CVC model is a classificatory scheme in which the characteristics are innate to the firm, irrespective of its industrial affiliation, thus reflecting its generic function in the marketplace.

The differentiation by function is a method of classification of internal departments or divisions in the organisation (Tosi, 2008). Other modes of differentiation of internal unit are by product, by customer, and by geography. The initial departmentation in nascent firms tends to be by function, so that the specialised skilled and activities of definable units may be formally distinguishable and their behaviour may now be explained as the imperative of their function (Morgeson and Hofmann, 1999; Tosi, 2008).

\subsection{CVC and the genetic makeup of the firm}

The CVC model resembles the differentiating factor of genetic makeup in the biological world, where organisms have similar basic structure, then differ along selected genes. The biological analogy has been applied to social and economic organisations (Govindarajan and Trimble, 2005). In the case of the CVC model, the firms differ on the basis of the function they perform in the marketplace. This distinction is analogous to the genetic differentiation between genders in biological organisms, where the organisms differ due to their role in the function of procreation and the survival of the species. Such organic-structural differences also translate into different modes of behaviour - as both biological organisms and firms play their inherent role in their environment (Bordia et al., 2005). 
Govindarajan and Trimble (2005, p.49) have suggested that the organisational DNA is composed of:

1 structure

2 staff

3 systems

4 culture.

The first three components are within the purview of managerial action. They can be changed and otherwise manipulated to suit the organisation's strategic planning. The dimension of culture, such as: valued notions about behaviour and embedded business assumptions, can also be changed by management actions - albeit with more effort and difficulty. The CVC model consists of embedded attributes of the firm which are nearly impossible to change - unless the function of the firm in the marketplace is changed (Taggart, 1995).

\subsection{The CVC model and transaction cost theory}

The transaction cost theory is an influential factor in the analysis of firms by their function in the marketplace. This paper will consider such impact in particular in the case of the firm as conduit (Williamson, 1981). A key difference between conduit and conduct firms in the CVC model is the ability of the firm to perform its function in the market at a lower cost and higher efficiency than the transaction handled directly between individuals. This paper will show that the lower the cost of transactions in the overall budget of the operation of the firm, the more it can be classified as content.

\subsection{Key dimensions of the CVC model}

There are six key dimensions that differentiate between conduit and content organisations. These diversions are shown in Table 1.

Table 1 Dimensions of CVC

\begin{tabular}{|c|c|c|}
\hline Key dimensions & Conduit & Content \\
\hline Immutability & $\begin{array}{l}\text { Easier for new entrants and } \\
\text { competitors to imitate the firm's } \\
\text { competencies. }\end{array}$ & $\begin{array}{l}\text { Difficult for new entrants and } \\
\text { competitors to imitate its } \\
\text { competencies. }\end{array}$ \\
\hline Substitutability & $\begin{array}{l}\text { Relatively easier for the firm to } \\
\text { replace resources. }\end{array}$ & $\begin{array}{l}\text { Difficult and complicated process for } \\
\text { the firm to replace/exchange } \\
\text { resources. }\end{array}$ \\
\hline $\begin{array}{l}\text { Malleability to } \\
\text { change }\end{array}$ & $\begin{array}{l}\text { Easy to change to upgrade and to } \\
\text { adapt to environmental dynamics. }\end{array}$ & $\begin{array}{l}\text { Needs to devote more resources to } \\
\text { adapt, to change, and to upgrade. }\end{array}$ \\
\hline $\begin{array}{l}\text { Focus of } \\
\text { transaction }\end{array}$ & $\begin{array}{l}\text { The focus is external to the firm - in } \\
\text { the marketplace. The firm intervenes } \\
\text { like a 'traffic cop'. }\end{array}$ & $\begin{array}{l}\text { The focus is internal and is the driver } \\
\text { of the transaction. }\end{array}$ \\
\hline Transferability & $\begin{array}{l}\text { Nearly impossible to move resources } \\
\text { around. They are fixed in the market. }\end{array}$ & $\begin{array}{l}\text { Firms have more flexibility to move } \\
\text { their content resources around. }\end{array}$ \\
\hline $\begin{array}{l}\text { Nature of } \\
\text { competition }\end{array}$ & $\begin{array}{l}\text { Firms compete on price leadership, } \\
\text { with intensive competition. }\end{array}$ & $\begin{array}{l}\text { Firms compete on quality, } \\
\text { differentiation and focus. }\end{array}$ \\
\hline
\end{tabular}


The dimensions describe the attributes or properties of the firm as conduit or content, so that the differences between firms in the structure and behaviour of the endogenous and exogenous variables are a good measure of the firm as conduit or content (Hambrick, 1983; Viladsen, 2013).

The first dimension is imitability. For conduit firms it is relatively easier for competitors and new entrants to imitate the competencies of the firm. For example, in the retail sector, competitors can introduce changes in the location of stores, the display of merchandise, the selection of merchandise, and the pricing of goods offered to consumers. These changes are relatively easy to implement, and their competitive impacts are very powerful, at a relatively manageable cost to the competitor.

The content firm is more secure. New entrants and competitors may find it more difficult to imitate the talent and the content property that the firm possesses. The entertainment industry is an example of firms who own artistic content which is not only unique and difficult to imitate, but also protected by laws which safeguard intellectual property.

Substitutability is the ease with which the firm and its competitors are able to substitute resources or competencies. Content firms, such as healthcare delivery organisations find it difficult to substitute talent for talent, particularly in replacing specialised caregivers. There is a need to match levels of education, training, experience, and even bedside manners and the ability to work with a team. Conversely, the conduit firm may find it much less difficult and onerous a problem by which it can replace humans and other resources.

Malleability to change is the third key dimension. It refers to the degree to which resources can be upgraded, improved, extended, or in general, be transformed. The conduit firm finds it easier and less costly to change and update its physical and human resources. For example, in the transportation industry, a trucking company can upgrade its fleet of vehicles and the training of its drivers with relative effectiveness in time and cost devoted to this change. A content firm such as a consulting company will devote considerable more resources and time to change, adapt and upgrade its human capita.

The locus of transaction is a key dimension of the CVC model which refers to the main locus of the economic activity in which the firm takes part. In the case of the firm as conduit, the locus of the economic transaction is outside the firm, in the marketplace. The firm as conduit intervenes in the transaction as a link between the transactors - similar to a police officer directing traffic. Conversely, the firm as content has the economic activity occurring inside the firm. This endogenous transaction drives the firm's intervention in the marketplace. In a way, the firm as content is the creator of the economic activity. A pharmaceutical company conducts most of its activity inside its boundaries, by researching and developing new drugs, which it then sells in the marketplace.

This key dimension defines the crucial difference between CVC firms. The manner in which the firm is involved in the transaction in the marketplace is a measure of the firm as conduit or content - with all the subsequent implications for competition and the strategic management of the firm (Reeves et al., 2015).

Transferability refers to the ability of the firm to move resources around. Consider the case of the transportation industry, more specifically the trucking or railroad freight companies. Since they are conduit firms, their economic transactions are outside their control, embedded in the marketplace. Roads and rails cannot be easily moved. The conduit firm is bounded to operate within the existing market infrastructure, so that it is 
very costly and ineffective to move its resources around. The implication for the firm is that its flexibility and competitiveness are highly restrictive.

Firms as content have more flexibility in moving their resources around. Pharmaceutical companies can move their R\&D facilities to other locations and their ability to do so depends on the firm's willingness to make this change. Healthcare delivery firms can move their medical resources to operate in other locations, including the implementation of telecommunications technologies in the emergence of tele-health. All this is feasible because these firms do not depend as much on the external conditions and infrastructure of the marketplace (Soo, 2010).

The first five key dimensions lead to the sixth dimension: The nature of competition. By virtue of the firm being conduit or content, the firm competes differently in the marketplace. This distinction based on the CVC model is in the type of competition as well as the intensity of the competitive pressures endured by the firm.

The firm as conduit competes primarily on price leadership as a generic strategy (Porter, 1979). The competition is relatively more intense than in the case of the firm as content. Companies in the retail and transportation sectors are illustrations of this type and level of competitions. Airlines, maritime and ground transportation firms offer consumers very similar services and equipment, so that the one variable in which they can differentiate themselves is in the price of their offering. Similarly, retail firms offer virtually the same facilities and merchandise as their competitors, thus price leadership is a competitive variable they can control.

Firms as content compete primarily on the quality of their offerings, so they are bound to employ the generic strategies of differentiation and focus. For example, professional firms in technology, law, or healthcare compete primarily on the quality and superior skills, knowledge and experience of their assets. Similarly, firms in the entertainment industry compete on the quality, uniqueness and attractiveness of their talented resources and the creative outputs of these resources. The focus of these firms on specific segments of the market will influence and attenuate the intensity of the competition. This is due to the ability of these firms to change the focus of their offerings to a different segment - with relative ease, manageable costs and time. Firms as conduits are constrained by the architecture and the make-up of the marketplace, hence, are limited in the flexibility they have to change the focus of their offerings. For example, railway firms would be hard-pressed to change their focus from freight to passenger services, because the railroads may not offer competitive access to stations in populated areas of their desired markets.

\section{The firm as conduit: definition and function in the market}

The firm as conduit plays the role of an intermediary, a link, and a go-between those in the marketplace who wish to acquire a product or service and those who wish to provide them with this or similar products or services. The firm as conduit does not necessarily make, produce, create or manufacture the devices, instruments, technologies or the means by which the firm links the participants in the transaction.

For example, transportation companies (airliners, railways, maritime, bus and taxi companies) move people from one location to another - by means of airplanes, trains, ships, buses and cars - but they use transportation equipment created and sold by other companies. Similarly, financial institutions, such as banks and traders in securities link 
those in the marketplace who have slack financial resources with those who need such resources for their personal and business requirements. Banks are the intermediaries between these two participants in the financial transaction. Hence, the modern bank is, in principle, very similar to the Italian citizen in the middle ages, sitting on a bench in a town square in Tuscany and transacting the exchange of economic assets between willing participants in the transaction.

In addition to the six key dimensions of the clarification scheme of firms as conduit or content (Figure 1), the question related to the need for the firm's participation in the marketplace would be 'can the parties to the transaction complete the transaction without the link provided by the firms as conduit?' The answer is that in many instances the parties can complete the transaction without the intermediary intervention by the firm as conduits.

For example, in the financial sector, individuals can lend money to other individuals without the need for banks. Individuals can also use their own vehicles for transport of other individuals. In the publishing industry, authors can use the internet to connect with readers without the intermediary services of a publishing company.

So, what does the firm as a conduit bring to the transaction that makes its function not only acceptable to the parties but in many cases also essential to the transaction?

\subsection{Defining the function of the firm as conduit}

Roth (2015) has wondered what role realtors continue to play in the real-estate market. The firms which function as brokers in this market are a good example of the firm as conduit. Although the parties to a real-estate transaction (buyers and sellers) have access to almost perfect information about the transaction, they nevertheless continue to employ realtors and to pay the price of this brokerage.

There are six contributions that the firm as conduit brings to the market transaction in which it participates as an intermediary. These contributions may explain the continuing need for the firm as conduit. Table 2 describes these contributions.

Table 2 The contributions of the firm as conduit to market transactions

\begin{tabular}{ll}
\hline Contribution & What the firm as conduit brings to the market \\
\hline The 'rolodex' effect & $\begin{array}{l}\text { A database of customers, suppliers, competitors and regulators; } \\
\text { established track of relationships with them. }\end{array}$ \\
$\begin{array}{l}\text { Task beyond what the } \\
\text { parties can or wish to do }\end{array}$ & $\begin{array}{l}\text { Expertise, experience and abilities beyond those of the parties to the } \\
\text { transaction: e.g., severity; safety; multi-tasking, etc. The firm as } \\
\text { conduit gives the parties a sense of reduced ambiguity and less } \\
\text { uncertainty in their dealing with turbulent environments. }\end{array}$ \\
$\begin{array}{l}\text { Advantages of size and } \\
\text { resources }\end{array}$ & $\begin{array}{l}\text { Ability to simultaneously handle a large number of transactions - } \\
\text { e.g., account holders, passengers, customers. }\end{array}$ \\
$\begin{array}{l}\text { Economics of scale } \\
\text { Level of specialisation }\end{array}$ & $\begin{array}{l}\text { Size allows for less costly performance of transactions. } \\
\text { Transactors are not equipped nor have specialised skills, experience, } \\
\text { knowledge or training to complete the transaction. }\end{array}$ \\
$\begin{array}{l}\text { Routineness and } \\
\text { repetitiveness, quality } \\
\text { and performance }\end{array}$ & $\begin{array}{l}\text { The firm as conduit mastered the routines and repetition of the } \\
\text { transaction over time and countless times, whereas transactors may } \\
\text { do it less frequently. By continuous presence in the market, the firm } \\
\text { as conduit creates its brand. }\end{array}$ \\
\hline
\end{tabular}


The rolodex effect is the database which the firm as conduit develops and maintain. A rolodex is a manual device holding small cards with names and other information of individual and of organisations with whom the firm interacts in its environment. The advanced versions are electronic databases stored in computers, telecommunication devices and physically distant reservoirs such as the 'cloud'. Individuals and organisations usually lack such databases, so they rely on these firms to provide them access to the specialised information. Realtors base their role in the market on their database of properties, the computed and current value of the properties, and their relation to other variables such as location and the educational and transportation availabilities.

Similarly, book publishers own databases of authors, printers, designers, bookstores and distributors. In addition to the database, publishers maintain relationships with these organisations, so that the individual author finds it to be very difficult to identify and to effectively transact with these entities.

Tasks beyond the parties' ability and willingness to undertake. For example, the firm as conduit performs tasks and multi-tasks such as security, safety, and ability to perform over long distances and with many customers, suppliers, competitors and reputations. Airlines can transport passengers across oceans, retailers can offer a large variety of merchandise, and insurance companies can offer protection in risky endeavours. These are examples of tasks that individuals and organisations are willing to 'outsource' to firms as conduit. In general, conduits offer the parties in the transaction a sense of less uncertainty and reduced ambiguity.

These are also examples of transaction costs (Williamson, 1981). When economic transactions become more complex and the parties to the transaction are unable to engage in all the ancillary or indirect requirements for a successful completion, they would be willing to pay a third party, thus adding to the cost of the transaction (Williamson, 1979).

Advantages of size and resources: Large firms as conduit have the necessary size and resources to conduct large-scale operations in its linking of the parties to the transaction. Airlines can transport large numbers of passengers and cargo across large distances whereas individuals or smaller firms are unable to do so. Retailers such as Wal-Mart, Walgreens and Amazon can offer a very large inventory of many products whereas smaller firms with fewer resources are unable to do - even within their niche or focused merchandising. Large resources also allow these firms as conduit to offer guarantees of cost, quality, and performance.

Economics of scale: Size and abundant resources give large firms as conduit advantages of lower costs and more efficient performance of their task in the transaction. Large cable companies can link consumers to venues of entertainment and to the internet with the efficiency and manageable cost that are unavailable to smaller operations. Similarly, large financial companies can offer their customers a variety of services at low cost, which smaller firms cannot afford to provide.

Level of specialisation: Parties to a transaction are not necessarily equipped with the knowledge, expertise, and, specialisation, nor do they have the experience needed to complete the transaction. The firm as conduit provides such specialisation. This advantage also includes the effective use of technology by the firm as conduit. Internet service providers (ISP) are examples of how these firms as conduit keep up with the ever-improving technologies.

Routineness and repetitiveness: The firm as conduit has mastered the task and the routine needed to effectively accomplish the task. Individuals and firms who are parties 
to the transaction lack such experience and may, at best, conduct such activity infrequently. By its routine and repetitive actions, the firm as conduit builds a reputation and a brand name for itself. Book publishers are a good example. As conduits, these firms only have the 'rolodex' and the brand name, so their message to the marketplace is that these firms are good conduits because they had repeatedly published successful books.

\subsection{Conduit is not synonymous with service}

Firms as conduit are not necessarily classified in the service sector of the economy. The traditional classification scheme of service firms, as distinct from manufacturing, is blurred. Service companies produce outputs such as software, and conversely, manufacturing companies offer an array of services to their customers. The firm as conduit links manufacturing firms to offer manufacturing, service firms to other service firms, and all possible combinations thereof.

For example, professional firms in accounting, law and management consulting are usually classified as service companies. Yet, they are content firms. Similarly, companies providing healthcare and entertainment have traditionally been regarded as service sector companies, yet they are content firms, not conduit.

A possible metric currently explored by the author to add precision to the classification of firms as conduit could be the amount of time and the complexity of the process needed to train an operator of the function of the firm as conduit in doing her/his job and in mastering the technology necessary for the job. Thus the initial training for employees in the retail, transportation, hospitality, and communications industries is much less onerous and time consuming than that of firms as content, such as healthcare delivery, law, or accounting.

\subsection{The firm as conduit: the illustrative case of Uber Inc.}

Uber Inc. was founded in 2009 by Travis Kalancik and Garrett Camp in the city of San Francisco. Within six years the company grew to an extent that in 2015, it operated in over 300 cities worldwide, and has received almost \$2 billion in venture capital.

Uber is based on an application for smartphones. The software links individuals who own and drive cars with individuals who desire a ride, then calculate the price of the ride, and charges the passenger's credit card for the ride. Uber took advantage of the internet and the rapid proliferation of smartphones as ubiquitous communication devices. Uber also exploited a glaring loophole in the regulatory system of cities, thus enabling the company to successfully compete with traditional municipal taxicab companies.

The premise of Uber is simple, yet offers an excellent illustration of a firm as conduit. The basic transaction in the transportation area occurs between one individual who has the means to provide a ride and another individual who wishes to be driven to a destination. Uber is acting as go-between or a conduit or a matchmaker in this transaction. Uber does not own the taxicab and its drivers are independent contractors whose relationship with Uber is on a ride-by-ride basis. The passenger does not pay the driver, and Uber collects the fee and acts on behalf of both the driver and the passenger, thus facilitating the transaction. This is a definition of the firm as conduit.

Table 1 show the dimensions of a firm as conduit which apply to the case of Uber. The company was able to circumvent the regulatory constraints that municipalities impose on licensed taxicab companies, including hiring and training of their drivers and 
the periodic inspections of their vehicles for safety purposes. In the case of Uber, since the transaction is person-to-person, the regulatory constraints have not been fully applicable.

\subsubsection{Uber's competition and challenges}

Uber has been challenged by established taxicab companies. A license for a taxicab in major cities is very expensive, due to the limited number of cabs licensed to operate on the city's streets. This initial investment forces the taxicab companies to add a fee to the price of a ride and puts them at a disadvantage with Uber. The lack of supervision and regulatory oversight has been the driver of numerous lawsuits by municipal authorities, and in many cases, resulted in regulatory constraints and licensing protocols imposed on Uber.

Moreover, legal challenges by Uber drivers have led to rulings that the drivers are employees of the company, not independent contractors. Hence, the company must pay the drivers benefits such as contributions to Social Security and Medicare. These challenges, if upheld by the courts, will transform Uber into a more traditional firm as conduit, similar to other transportation companies such as trucking and airlines.

Uber also faces competition from new entrants such as Lyft and other ridesharing companies. Lyft entered the market in 2012 and by 2015, has raised over $\$ 1$ billion in venture capital and operated in over 60 US cities. These competitors are able to rapidly establish themselves as serious alternatives to Uber, primarily due to the nature of these companies as conduits. They find it is relatively easy to imitate Uber, and easy to carve a respectable portion of the ridesharing market (see Table 2).

A competitive analysis of Uber and similar companies must be anchored in the CVC model. The attributes of the firm as conduit better explains the genesis and rise of a company such as Uber. As a conduit, Uber was able to take advantage of the person-to-person ridesharing and do so with the advances in telecommunication (Geisler, 1997).

\subsection{The firm as conduit: the role of technology management}

Firms as conduit require some degree of technology management. These firms are 'go between' other companies in the marketplace, thus do not need technological innovations to compete. Their need for technology is limited by the role they are playing in the market. The need for technology for such firms is to ensure that the firm as conduit can indeed interact with the firms in the marketplace. Thus, the technological innovations of the firm as conduit will be to 'stay connected' to the market. A good example is the role that information and telecommunication technologies (ICT) play in keeping the firm as conduit relevant to its market involvement. When firms in the market automate and computerise their processes and communication technologies, the firm as conduit must adjust and follow with technologies sufficient to continue their uninterrupted involvement. 


\section{The firm as content: definitions and function in the marketplace}

The firm as content differs from conduit in all six key dimensions in Table 1. The firm as content has its locus of transaction internally. This firm drives the transaction in the marketplace; it shapes the transaction, and is one of the key parties to the transaction.

Content can be broadly defined with the following criteria:

1 what we know in the firm: corporate experiences; explicit knowledge; whatever the firm possesses in its records, files, and organisational memory (Geisler, 2006)

2 what our people know: tacit knowledge of our employees; their experience; their skills and their training (Geisler, 1999a)

3 the technology the firm possesses which allows the firm to make products and services, and to transact them in the market (Thompson, 1967)

4 intellectual property assets which allow the firm to conduct its business in the marketplace, but which are not necessarily directly related to the firm's strategy.

The firm as content can also be defined by the processes and outcomes it generates. These include:

1 innovations, some of which are revolutionary

2 constant improvements in products and services, including improvements in the means, technologies, and methods of production and distribution

3 investments in the 'sources of content', namely the intellectual assets, human resources, and the knowledge-base of the firm

4 cooperation with other firms, government and not-for-profit organisations and the sharing of content with these collaborative entities.

\subsection{The locus of the transaction and contributions to the market}

Content is developed from inside the firm as content. The more the firm is able to create its own content, the more it is able to incorporate and adapt content from its environment. This concept of 'absorptive capacity' describes an important aspect of the firm's ability to procure resources (Lane et al., 2006).

The firm as content is a driver of the economy. It brings to the market not only products and services, but also an economic engine which facilitates and engenders economic growth. This type of firm creates the transaction and is a crucial party to it.

Table 3 shows the contributions of the firm as content to the marketplace. These contributions are categorised as tangibles and intangibles. They include internal processes of the firm and its outputs. 
Table 3 The contributions of the firm as content to the marketplace

\begin{tabular}{|c|c|}
\hline Contributions & What the firm as content brings to the marketplace \\
\hline \multicolumn{2}{|l|}{1 Tangibles } \\
\hline Innovations & $\begin{array}{l}\text { New and improved products, methods, services, ways and means } \\
\text { of production, distribution, and management }\end{array}$ \\
\hline $\begin{array}{l}\text { Investments to improve } \\
\text { the 'source of content' }\end{array}$ & $\begin{array}{l}\text { The firm invests in intellectual assets and knowledge of its human } \\
\text { resources, thus creating a knowledgeable and skilled workforce }\end{array}$ \\
\hline $\begin{array}{l}\text { Standards and } \\
\text { benchmarks }\end{array}$ & $\begin{array}{l}\text { The firm develops and helps to establish standards and } \\
\text { benchmarks/measures of economic activities }\end{array}$ \\
\hline \multicolumn{2}{|l|}{2 Intangibles } \\
\hline $\begin{array}{l}\text { Cooperation and sharing } \\
\text { with other entities }\end{array}$ & $\begin{array}{l}\text { The firm collaborates with other firms, government organisations } \\
\text { and not-for-profit, thus sharing its knowledge and experience and } \\
\text { adding to the pool of knowledge in the market }\end{array}$ \\
\hline $\begin{array}{l}\text { Inputs to the cultural } \\
\text { landscape }\end{array}$ & $\begin{array}{l}\text { The firm contributes to and helps to shape the cultural attributes } \\
\text { such as: fashion, consumer preferences, and technologies }\end{array}$ \\
\hline $\begin{array}{l}\text { Inputs to the general } \\
\text { welfare and the standards } \\
\text { of living of the general } \\
\text { public }\end{array}$ & $\begin{array}{l}\text { The firm's outcomes, such as innovative and affordable products } \\
\text { in hygiene, medicine, recreation and education elevate the overall } \\
\text { standard of living and the health and longevity of the population }\end{array}$ \\
\hline
\end{tabular}

\subsection{The nature of content}

Unlike the firm as conduit, the firm as content is encumbered with the inherent attributes of content as both strengths and weaknesses. The strengths of the content are the relative resilience of content to imitation and competition and the benefits from some measure of protection offered by governments in recognition of the rights of ownership of intellectual property.

The weaknesses of content are primarily focused on the sensitivity of content to the dynamic and often unforeseen peculiarities of the marketplace. The firm as content is under constant pressure to manage the 'deterioration' or 'obsolescence' of content, due to the age of the content (how long has it been in the market) and to pressure from consumers, competitors, and regulators. These pressures include:

1 market demands for things that are 'new' and more exciting

2 new generation of consumers with new fads, new styles, new technical aptitudes and preferences

3 innovations by competitors who take advantage of the changing trends in the marketplace

4 the cumulative effects of obsolescence and market pressures for change.

The demands on the life cycle of the firm as content determine the adaption by the firm of the structure and the strategy which best serves the interests of the firm. For example, companies in the apparel industry have low R\&D intensity but their success and survival depend on the volatility of the market. Several firms in this industry have endured decades of continuous changes in fashions and preferences of the consumers and by flexibly changing their content to fit such changes were able to survive and to prosper. 
Brand names such as Adidas, Nike, Levi Strauss, Liz Claiborne, and Ralph Lauren have persevered in the face of aggressive competition.

\subsection{The firm as content: the role of technology management}

The firm as content needs technological innovation to compete in the marketplace. This type of firm produces, and markets products and services. In order to maintain its competitive advantages, this firm must be current in its technologies of production and marketing. Whether the firm competes on price or quality, its strategic option will require competitive structures, processes and strategies. Its technological innovation is a requirement for its market competition, and the management of such technologies must ensure effectiveness and efficiency of operations, manufacturing, and marketing.

\section{The hybrid form of CVC}

In the CVC model, the firm is neither pure conduit nor pure content. The firm is a hybrid form of the CVC model. It has attributes of both conduit and content. For example, 'rolodex' firms such as real estate agencies lack some content in the form of specific knowledge and skills, and a brand which emerged from their experience. In addition to their contributions to the marketplace (Table 2), these dimensions of content may explain why such firms are still successfully operating in the age of the internet (Roth, 2015).

Similarly, firms as content may have some elements of conduit. Faced with market demands for vertical integration, firms in the entertainment industry purchase and operate theatres, television studios, and similar outlets. Oil companies acquire and operate transport companies (tankers and trucks) and they also build and operate pipelines.

These structural arrangements of vertical integration are not dictated only by economic considerations. These firms believe that their transactions are critical to the flow of their content to the marketplace. Therefore, they prefer to have control over the conduit contributions to their transaction, irrespective of cost.

So, how do we categorise the firm as conduit or content? As described above in this paper, the main function of the firm determines its type in the CVC model. In the case of a conduit firm employing some content, such content contributes to the firm's function. Content firms deploying conduit elements engage in such activities to better manage their content. For example, energy companies such as oil and gas can transport their products via the services of other firms as conduit. They prefer to do so themselves because of the added sense of security and to reduce their uncertainty in their already complex and turbulent environments.

\section{CVC: function drives strategy}

Current models of strategic choices for the firm's competitive effort advocate generic strategies and their application across industries (Porter, 1980; Murray, 1988). The key distinction among firms is their classification by products or services within the larger category of the industry (Thacker and Handscombe, 2003).

As firms grow and evolve, they pursue a life trajectory which is similar to the growth of biological entities. The function of the firm in the marketplace becomes more clarified, 
less ambiguous, and better understood by the market. As the firm reaches this stage, its function dictates the choice of strategy.

As shown in Table 1 in the definition of the nature of competition and the discussion of the theoretical background of strategic competitiveness, the literature has largely focused on the role played by endogenous and exogenous variables. How would the firm behave in its competitive effort based on the ecological attributes of its environment, versus how the firm would employ its endogenous competencies? Researchers have explored these two sets of variables in their research for the 'right' formula (Hambrick, 1983; Schmidt and Keil, 2013; Taggart, 1995; Winter, 2003).

The CVC model attempts to contribute to the analytical template for the choice of strategies. The CVC model offers a framework which precedes the analysis of the endogenous and exogenous variables. The function of the firm - as conduit or content dictates the strategy which the firm should employ, whereby the firm marshals its endogenous capabilities to effectively compete, thus to adapt to the changes in its external environment (Adegebesan, 2009).

Current models propose the application of a strategic choice as a generic formula for any firm, with the constraints of the industrial affiliation and the architecture of its internal resources - as they are posited against the dynamic composition of exogenous variables. The CVC model proposes an underlying analysis - as a substrate which limits and directs the subsequent analyses of internal and external variables in the search for an effective strategy.

Table 1 lists the differences in the key dimensions between the firm as CVC. The dimensions of 'locus of transactions' and 'nature of competition' for example, show with abundant clarity that each category of the firm means that the firm is challenged by a very distinct array of competitive variables in its external environment. The firm as conduit faces competitors which have relatively few barriers to entry and which compete on a small number of easily attained comparative advantages. Examples include retail firms which can enter the market with few comparative advantages, such as location, internal display of merchandise, more selection, or lower prices.

The analysis of endogenous variables is also driven by the CVC model. The firm as content competes on its internal assets, its intellectual property, and its other assets/resources, such as experience and brand. These attributes are more difficult to imitation by competitors, but those competitors able to do so, present a formidable challenge to the firm as content upon its decision to select an effective strategy. For example, a pharmaceutical company marketing a drug for the treatment of high cholesterol may be faced with a competitor offering a similar drug based on a different biological process in the body. If this drug is more effective, the competition is no longer based on price or availability, or the mode of marketing - all critical to the competitive position of the firm as conduit.

In summary, the choice of a strategy must originate with the substrate of the CVC model. The general strategies such as price leadership or differentiation are subordinated to the type of firm per its function in the market, conduit or content. This CVC classification is the very initial template for the analysis of the competitive effort of the firm. 


\section{CVC: function drive structure}

As firms evolve and their function is established in the marketplace, changes to the structure are introduced, organically and by design. When these processes unfold, the firm as conduit tends to have a structure which is flat, more formalised, standardised, and centralised. The firm as content tends to have a more layered structure, with higher specification, less formalisation and higher decentralisation.

Table $4 \quad$ CVC and structural dimensions

\begin{tabular}{|c|c|c|}
\hline Structural dimensions* & Conduit & Content \\
\hline Specialisation & $\begin{array}{l}\text { There is a tendency for less } \\
\text { specialisation due to the } \\
\text { attributes of the transaction and } \\
\text { the means of conduit. }\end{array}$ & $\begin{array}{l}\text { The talent and intellectual } \\
\text { content require higher level of } \\
\text { specification. }\end{array}$ \\
\hline Standardisation & $\begin{array}{l}\text { Conduit firms are more } \\
\text { standardised as their operations } \\
\text { are tailored to the stable } \\
\text { transaction. }\end{array}$ & $\begin{array}{l}\text { Although this type of firm } \\
\text { strives for increased standards, } \\
\text { the need for flexibility keeps } \\
\text { standardisation low. }\end{array}$ \\
\hline Formalisation & $\begin{array}{l}\text { Conduit firms are more formal } \\
\text { due to the less complex nature of } \\
\text { their function. }\end{array}$ & $\begin{array}{l}\text { The talent and intellectual } \\
\text { content require flexibility, hence } \\
\text { less formalised structure. }\end{array}$ \\
\hline Centralisation & $\begin{array}{l}\text { There is a need for centralisation } \\
\text { due to the convergence of } \\
\text { operations to the sole purpose of } \\
\text { the function. }\end{array}$ & $\begin{array}{l}\text { The need for flexibility and } \\
\text { differentiation requires more } \\
\text { decentralisation. }\end{array}$ \\
\hline Configuration & $\begin{array}{l}\text { There is a certain preponderance } \\
\text { of endogenous variables in the } \\
\text { configuration. }\end{array}$ & $\begin{array}{l}\text { There is a certain increased role } \\
\text { of exogenous attributes in the } \\
\text { configuration. }\end{array}$ \\
\hline
\end{tabular}

The fundamental driving force is the function of the firm in the market (Geisler, 2015). As the configuration of structural attributes is shaped by the firm, two main processes are at work (Blackburn, 1982). The first is the need of the structural arrangement to serve the function of the firm in the market. This is the initial characterisation of the firm as a presence in the marketplace. This is also the structural arrangement answering the question, 'what business are we in?'

The structure of the firm has a dual purpose, embedded in the two main processes. The first is to serve the need of the function of the firm. Once this need has been satisfied, the structure must then satisfy the second need of the firm to compete in its market. In this second purpose, many organisation scholars have examined the structural arrangements which are designed to answer the question, 'how we compete effectively?'

Table 4 shows the differences in the five dimensions of the firm's structure - between the firm as conduit and as content. Such differences combine to form a distinct structural configuration which is based on the analysis of the firm's function in its market and its competitive stance. The CVC model thus offers a more basic explanation of why the firm adapts a certain structural configuration. 


\subsection{CVC and structural configurations}

How does the firm select, assemble and cluster its attributes or characteristics into a workable configuration and, what are the criteria, sources, or forces which cause or impinge upon such configuration? Research into these questions has been an important component of theories of organisation and of strategy (Fiss, 2007).

This research has focused on the formation of patterns or theoretically-derived configurations, which then allow for empirical measures and observations - thus leading to the establishment of typologies (Meyer et al., 1993). The criteria for such clustering have been the firm's ability to manage the dynamics of a volatile environment and to effectively compete and survive in it (Vorhies and Morgan, 2003). Firms form clusters of their attributes and capabilities in general patterns which can be detected and measured by researchers.

Critics of the configurational approach have argued that the empirical models and methods have not been fitted to measure and to analyse configurations, particularly in their relation to the firm's strategic performance. Fiss (2007), for example, argued that configurational concepts such as equifinality "have not been well translated into empirical models. For one thing, the suggestion that there are frequently multiple paths to an outcome stands in contrast to conventional methods of multivariate regression analysis, which estimate a single path for all cases under examination" [Fiss, (2007), p.1181]. The alternative method would be set-theory, whereby the configuration itself not its elements - as the focus of the analysis.

The CVC model elegantly expands the explanatory power of configurational theory, while preserving the holistic approach. The CVC model identifies the sources or criteria that drive the configuration. Based on the dual-purpose of why the firm selects its structural configuration, the fundamental typology of CVC emerges. The needs of the firm to fulfil its function and to be competitive in its environment are the basic sources of structural configuration. These needs also dictate whether the firm adopts more or less structure. Davis et al. (2009) for example, found that "...it is better to err on the side of too much structure" (p.413), and that "...entrepreneurial organisations should quickly add structure in all environments, while established organisations are better off seeking predictable environments unless they can devote sufficient attention to managing a dissipative equilibrium of structure (i.e., edge of chaos) in unpredictable environments" (p.413).

This and similar research combined empirical and simulation methods to arrive at models of structure. However, these studies lack an underlying and fundamental conceptual framework which would explain why organisations prefer one type and amount of structure over another (Oliver and Ebers, 1998). CVC offers such an analytical framework.

First, the firm will employ a structure necessary only to accomplish its function in the market. This may result in an economically minimal configuration. For example, healthcare delivery organisations will focus on medically necessary facilities and resources, at the expense of the resources devoted to hospitality (e.g., food or accommodations such as private or semi-private rooms). Similarly, conduit firms such as airlines will focus on moving people and cargo across distances, at the expense of amenities such as food and entertainment.

Secondly, the firm will opt to add structure beyond what is needed only for its function due to competitive pressures from its environment. Lawrence and Lorsch (1967) 
had identified this phenomenon of 'differentiation' and the ability of the firm to adapt its structure to the volatility of its environment (Pettus, 2003).

In summary, the firm as conduit will structure itself differently than the firm as content. The forces of the function and competition act differently for each type of firm in the CVC model. These different behaviours, driven by the dual-purpose model, provide a more promising explanation of how and why the firm adapts its structural configuration.

\section{The case of the merger of AOL/Time-Warner}

The merger of America on Line (AOL) and Time-Warner in 2000 is widely studied in business schools. In this paper, the case is briefly analysed with the purpose of providing an alternative and more plausible explanation of the failure of the merger through the prism of the CVC model.

In the year 2000 AOL and Time-Warner merged in a stock swap of \$164 billion. At the time the merge seemed to be a 'match made in heaven'. AOL brought to the merge its internet connection with over 20 million subscribers. Time-Warner was the powerhouse of media and entertainment. Investors flocked to the deal. They were convinced, as Steve Case, the chairman of AOL and the combined concern had promised that the new company will be a digital media conglomerate, with access to every home in the USA and then, even globally. The market capitalisation of the new company was $\$ 350$ billion at the time of the merger (Rubinfeld, 2001; Thompson, 2003).

In 2009, after years of difficulties and decline, the board of directors of Time-Warner decided to divest itself from the merger. At the time of the breakup, the market capitalisation of the combined company had lost almost $90 \%$ of its original value, to about $\$ 40$ billion. The two companies went their separate yet unequal ways. AOL's number of subscribers had continually declined: in 2008, AOL reported 6.8 million; in 2009, 5 million and in 2014, only 2.2 million. Time-Warner continued to expand and grow (Malone and Turner, 2010; Wade, 2010).

Conventional theories explain the failure of the merger as the result of two forces. The first was the ill-timing of the merger, because soon afterwards the dot-com collapse had occurred and then came the economic recession following the attacks of September 11, 2001. The second and widely held cause was the conflict between the different cultures of the two companies. AOL was a digital or 'click' company and Time-Warner was a traditional 'brick' company (Peltier, 2004; Malone and Turner, 2010).

These are superficial explanations of a much more fundamental difference between the two companies. The analysis of this case from the CVC perspective shows the merger of two companies - AOL as a conduit and Time-Warner as content. Due to this basic makeup the two companies - although merged - continued their evolution on two very different trajectories. Figure 1 depicts the gap which evolves over the years of the merger.

As the internet, digital access and e-commerce became more mature, standardised, and ubiquitous, competitors found it easier to enter the market and directly compete with AOL. The merged company seemed to have failed to utilise the content provided by Time-Warner as a strategic advantage in the struggle against competitors, namely, the phone companies and new telecommunication firms such as Comcast. As this phenomenon evolved, AOL's rolodex (the number of subscribers) began to shrink. Time-Warner, a content company, continued its strategic growth and soon started looking 
elsewhere for a strategic partner which will allow it to propagate its content onto this new medium of the digital world. The internal cultural incompatibilities were marginal to the realities of the CVC phenomenon, and perhaps were even more noticeable and their destructive presence was enhanced because of the divergent trajectories of the two firms.

Figure 1 The different market trajectories of AOL and Time-Warner

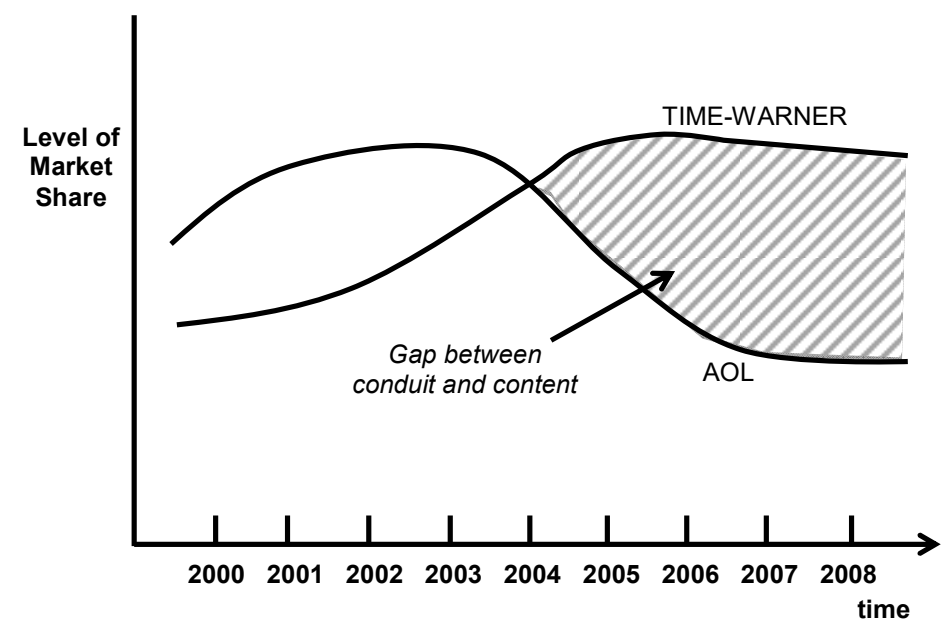

Whenever conduit and content firms merge, the conduit companies all face a more challenging evolution of competitive sustainability (Table 2). The critical strategic challenge of such a merger is to utilise the comparative advantages of both firms in the configuration of their competitive presence in the market. The content provided by the content firm needs to be added to the attributes of the firm as conduit (Table 3). AOL and Time-Warner failed to do so, and their merger had collapsed.

\section{Further research and applications}

The CVC model has potential applications in a variety of industries. Prime candidates are: retail, banking, chemicals, consumer electronics, software, medical instruments, transportation, hospitality, healthcare delivery, and government. Further studies should explore empirically the strategic effects of the different types of organisations: CVC.

The CVC model would also benefit from studies that explore its analytical framework in conjunction with other theories and models. The explanatory power of the CVC model should be compared with other models, and the fundamental attributes of the CVC model should be tested against other models of the endogenous and exogenous variables of the strategic competitiveness of the firm.

\section{Acknowledgements}

The author is grateful for the support for this research provided by the Stuart School of Business Summer Research grant. 


\section{References}

Adegebesan, J.A. (2009) 'On the origins of competitive advantage strategic factor markets and heterogeneous resource complementarity', Academy of Management Review, Vol. 34, No. 3, pp.463-475.

Akan, O., Richard, A., Helms, M. and Spralls, S. (2006) 'Critical tactics for implementing Porter's generic strategies', Journal of Business Strategy, Vol. 27, No. 2, pp.43-53.

Aragon-Correa, A. and Sharma, A. (2003) 'A contingent resource-based view of the proactive corporate environmental strategy', Academy of Management Review, Vol. 28, No. 1, pp.71-88.

Autio, E., Sapienza, H. and Almeida, J. (2000) 'Effects of age at entry, knowledge intensity, and imitability on international growth', Academy of Management Journal, Vol.435, No. 3, pp.909-1014.

Barney, J. and Peteraf, M. (2014) 'Comment on Hashai and Buckeley: transactions costs, capabilities, and corporate advantage considerations in theories of the multinational enterprise', Global Strategy Journal, Vol. 4, No. 1, pp.70-73.

Barney, J. and Zajac, E. (1994) 'Competitive organizational behavior: toward an organizationallybased theory of competitive advantage', Strategic Management Journal, Vol. 15, No. 2, pp.5-9.

Barney, J., Ketchen, D. and Wright, M. (2011) 'The future of resource-based theory: revitalization or decline?', Journal of Management, Vol. 37, No. 5, pp.1299-1315.

Berman, S., Down, J. and Hill, C. (2002) 'Tacit knowledge as a source of competitive advantage in the National Basketball Association', Academy of Management Journal, Vol. 45, No. 1, pp.12-31.

Blackburn, R. (1982) 'Dimensions of structure: a review and reappraisal', Academy of Management Review, Vol. 7, No. 1, pp.59-66.

Bordia, R., Kronenberg, E. and Neely, D. (2005) Innovation's OrgDNA, Booz, Allen, Hamilton Report, Booz, Allen Hamilton, New York.

Brown, S. and Blackmon, K. (2005) 'Aligning manufacturing strategy and business-level competitive strategy in new competitive environments: the case for strategic resonance', Journal of Management Studies, Vol. 42, No. 4, pp.793-815.

Campbell, B., Coff, R. and Kryscynski, D. (2012) 'Rethinking sustained competitive advantage from human capital', Academy of Management Review, Vol. 37, No. 3, pp.376-395.

Carroll, G. and Hannan, M. (1995) Organizations in Industry: Strategy, Structure, and Selection, Oxford University Press, New York.

Conner, K. and Prahaled, C. (1996) 'A resource-based theory of the firm: knowledge versus opportunities’, Organization Science, Vol. 7, No. 5, pp.477-501.

Davis, J., Eisenhardt, K. and Bingham, C. (2009) 'Optimal structure, market dynamism, and the strategy of simple rules', Administrative Science Quarterly, Vol. 54, No. 3, pp.413-452.

Fiss, P. (2007) 'A set-theoretic approach to organizational configurations', Academy of Management Review, Vol. 32, No. 4, pp.1180-1198.

Geisler, E. (1997) Managing the Aftermath of Radical Corporate Change: Reengineering, Restructuring, and Reinvention, Greenwood Publishing Group, Westport, CT.

Geisler, E. (1999a) 'Harnessing the value of experience in the knowledge-driven firm', Business Horizons, Vol. 42, No. 3, pp.18-26.

Geisler, E. (1999b) Methodology, Theory, and Knowledge in the Managerial and Organizational Sciences, Greenwood Press, Westport, CT.

Geisler, E. (2006) 'A taxonomy and proposed codification of knowledge and knowledge systems in organizations', Knowledge and Process Management, Vol. 13, No. 1, pp.1-12. 
Geisler, E. (2010) 'Measuring the contributions of knowledge management systems to the strategic competitiveness of organizations: a review and a model', International Journal of Innovation and Technology Management, Vol. 7, No. 2, pp.89-107.

Geisler, E. (2015) CVC and Configuration Theory in Organizational Analysis: A Review and Fundamental Typology, Stuart School of Business, Illinois Institute of Technology, Working Paper 2015/4.

Govindarajan, V. and Trimble, C. (2005) 'Organizational DNA for strategic innovation', California Management Review, Vol. 47, No. 3, pp.47-76.

Granstrand, O., Patel, P. and Pavitt, K. (1997) 'Multi-technology corporations: why they have 'distributed' rather than 'distinctive core' competencies', California Management Review, Vol. 39, No. 4, pp.8-25.

Grant, R. (1996) 'Toward a knowledge-based theory of the firm', Strategic Management Journal, Winter, Vol. 17, Special Issue, pp.109-122.

Hambrick, D. (1983) 'An empirical typology of mature industrial-product environments', Academy of Management Journal, Vol. 26, No. 2, pp.213-230.

Hannan, M. and Freeman, J. (1993) Organizational Ecology, Harvard University Press, Cambridge, MA.

Hax, A. and Mahluf, N. (1983) 'The use of the growth-sharp matrix in strategic planning', Interfaces, Vol. 13, No. 1, pp.46-60.

Heyes, C. and Hull, D. (Eds.) (2001) Selection Theory and Social Construction: The Evolutionary Naturalistic Epistemology of Donald T. Campbell, SUNY Press, Albany, NY.

Holahan, P., Sullivan, Z. and Markham, S. (2014) 'Product development as core competence: how formal product development practices differ for radical, more innovative and incremental product innovations', Journal of Product Innovation Management, Vo. 31, No. 2, pp.329-345.

Keidel, R. (1994) 'Rethinking organizational design', Academy of Management Executive, Vol. 6, No. 4, pp.12-28.

Lane, P., Koka, B. and Pathak, S. (2006) 'The reification of absorptive capacity: a critical review and rejuvenation of the construct', Academy of Management Review, Vol. 31, No. 4, pp.833-863.

Lawrence, P. and Lorsch, J. (1967) 'Differentiation and integration in complex organizations', Administrative Science Quarterly, Vol. 12, No. 1, pp.1-47.

Lim, G-E. (1994) 'Using generic strategies: some caveats', Singapore Management Review, Vol. 16, No. 1, pp.43-48.

Magretta, J. (2011) Understanding Michael Porter: The Essential Guide to Competition and Strategy, Harvard Business School Press, Boston, MA.

Malone, D. and Turner, J. (2010) 'The merger of AOL and Time Warner: a case study', Journal of the International Academy of Case Studies, Vol. 16, No. 8, pp.151-156.

Meyer, A., Tsui, A. and Hinings, C. (1993) 'Configurational approaches to organizational analysis', Academy of Management Journal, Vol. 36, No. 6, pp.1175-1195.

Miller, D. and Friesen, P. (1986a) 'Porter's (1980) generic strategies and performance: an empirical examination with American data, part I: testing Porter', Organization Studies, Vol. 7, No. 1, pp.37-55.

Miller, D. and Friesen, P. (1986b) 'Porter's (1980) generic strategies and performance: an empirical examination with American data, part II: performance implications', Organization Studies, Vol. 7, No. 3, pp.255-261.

Morgeson, F. and Hofmann, D. (1999) 'The structure and function of collective constructs: implications for multilevel research and theory development', Academy of Management Review, Vol. 24, No. 2, pp.249-265.

Morrison, A. and Wensley, R. (1991) 'Boxing up or boxed in?' A short history of the Boston Consulting Group share/growth matrix', Journal of Marketing Management, Vol. 7, No. 2, pp.105-129. 
Murray, A. (1988) 'A contingency view of Porter's 'genetic strategies', Academy of Management Review, Vol. 13, No. 3, pp.390-400.

Oliva, T., Day, D. and MacMillan, I. (1988) ‘A generic model of competitive dynamics', Academy of Management Review, Vol. 13, No. 4, pp.374-389.

Oliver, A. and Ebers, M. (1998) 'Networking network studies: an analysis of conceptual configurations in the study of inter-organizational relationships', Organization Studies, Vol. 19, No. 4, pp.549-583.

Oliver, C. and Holzinger, I. (2008) 'The effectiveness of strategic political management: a dynamic capabilities framework', Academy of Management Review, Vol. 33, No. 2, pp.496-520.

Peltier, S. (2004) 'Mergers and acquisitions in the media industries: were failures really unforeseeable?', Journal of Media Economics, Vol. 17, No. 4, pp.261-278.

Pettus, M. (2003) 'Successfully competing in the deregulated trucking industry: a resource-based perspective', Advances in Competitiveness Research, Vol. 11, No. 1, pp.46-65.

Porter, M. (1979) 'The structure within industries' and companies' performance', Review of Economics and Statistics, Vol. 61, No. 2, pp.214-227.

Porter, M. (1980) Competitive Strategy: Techniques for Analyzing Industries and Competitors, The Free Press, New York.

Porter, M. (1985) Competitive Advantage: Creating and Sustaining Superior Performance, The Free Press, New York.

Prahalad, C.K. and Hamel, G. (1990) 'The core competence of the corporation', Harvard Business Review, May/June, Vol. 68, No. 3, pp.79-91.

Pugh, D., Hickson, D., Hinings, C. and Turner, C. (1968) 'Dimensions of organization structure', Administrative Science Quarterly, Vol. 13, No. 1, pp.65-105.

Ray, G., Ling, X. and Barney, J. (2013) 'Impact of information technology capital on firm scope and performance: the role of asset characteristics', Academy of Management Journal, Vol. 56, No. 4, pp.1125-1147.

Reed, K., Lubatkin, M. and Srinivasan, N. (2006) 'Proposing and testing an intellectual capital-based view of the firm', Journal of Management Studies, Vol. 43, No. 4, pp.867-893.

Reeves, M., Haanaes, K. and Sinha, J. (2015) Your Strategy Needs a Strategy: How to Choose and Execute the Right Approach, Harvard Business Review Press, Boston, MA.

Roth, A. (2015) Who Gets What - and Why: The New Economics of Matchmaking and Market Design, Eamon Dolan/Houghton Mifflin Harcourt, New York.

Rubinfeld, D. (2001) 'Open access to broadband networks: a case study of the AOL/Time Warner merger', Berkeley Technology Law Journal, Vol. 16, No. 2, pp.631-675.

Schilke, O. (2014) 'Second-order dynamics capabilities: how do they matter?', The Academy of Management Perspectives, Vol. 28, No. 4, pp.368-380.

Schmidt, J. and Keil, T. (2013) 'What makes a resource valuable? Identifying the drivers of firm-idiosyncratic resource value', Academy of Management Review, Vol. 38, No. 2, pp.206-228.

Shieh, C-J. (2011) 'Management innovation, corporation core competencies and corporate culture: the impact of relatedness', Applied Economic Letters, Vol. 18, No. 12, pp.1121-1124.

Singh, J. and Lumsden, C. (1990) 'Theory and research in organizational ecology', Annual Review of Sociology, Vol. 16, No. 2, pp.161-195.

Snow, C. and Hrebiniak, L. (1980) 'Strategy, distinctive competence, and organizational performance', Administrative Science Quarterly, Vol. 25, No. 2, pp.317-336.

Soo, C. (2010) 'Product life cycle theory and the maturation of the internet', Northwestern University Law Review, Vol. 104, No. 2, pp.641-670.

Taggart, J. (1995) 'Strategy formulation in declining industries: a biology paradigm', Journal of Marketing Management, Vol. 11, No. 3, pp.295-314. 
Thacker, C. and Handscombe, B. (2003) 'Innovation, competitive position and industry attractiveness: a tool to assist SMEs', Creativity and Innovation Management, Vol. 12, No. 4, pp.230-239.

Thompson, D. (2003) 'AOL, Time Warner, Terra Lycos, Vivendi, and the transformation of marketing', Journal of Business Research, Vol. 56, No. 11, pp.861-867.

Thompson, J. (1967) Organizations in Action: Social Science Bases of Administrative Theory, McGraw Hill College, New York, NY.

Tosi, H. (2008) Theories of Organization, Sage Publications, San Francisco, CA.

Usher, J. and Evans, M. (1996) 'Life and death along gasoline alley: Darwinian and Lamarckian processes in a differentiating population', Academy of Management Journal, Vol. 39, No. 5, pp.1428-1466.

Viladsen, A. (2013) 'Similarity or difference? The relation between structure and strategy isomorphism in public organizations', British Journal of Management, Vol. 24, Supplement, pp.62-75.

Vorhies, D. and Morgan, N. (2003) 'A configuration theory assessment of marketing organization fit with business strategy and its relationship with marketing performance', Journal of Marketing, Vol. 67, No. 1, pp.100-115.

Wade, J. (2010) 'The failed merger of AOL/Time Warner', Risk Management, Vol. 57, No. 4, pp.22-23.

Wernerfelt, B. (1984) 'A resource-based view of the firm', Strategic Management Journal, Vol. 5, No. 2, pp.171-180.

West, P. and DeCastro, J. (2001) 'The Achilles heel of firm strategy: resource weakness and distinctive inadequacies', Journal of Management Studies, Vol. 38, No. 3, pp.417-442.

Williamson, O. (1979) 'Transaction-cost economics: the governance of contractual relations', Journal of Law and Economics, Vol. 22, No. 3, pp.233-262.

Williamson, O. (1981) 'The economics of organization: the transaction cost approach', American Journal of Sociology, Vol. 87, No. 4, pp.548-577.

Winter, S. (2003) 'Understanding dynamic capabilities', Strategic Management Journal, Vol. 24, No. 10, pp.991-995.

Woodward, J. (1965) Industrial Organization: Theory and Practice, Oxford University Press, New York.

Yuchtman, E. and Seashore, S. (1967) A system resource approach to organizational effectiveness', American Sociological Review, Vol. 32, No. 6, pp.891-903.

Yung-Hsiang, C. and Chian-Yu, Y. (2007) 'Core competencies and sustainable competitive advantage in air-cargo forwarding: evidence from Taiwan', Transportation Journal, Vol. 46, No. 3, pp.5-21. 